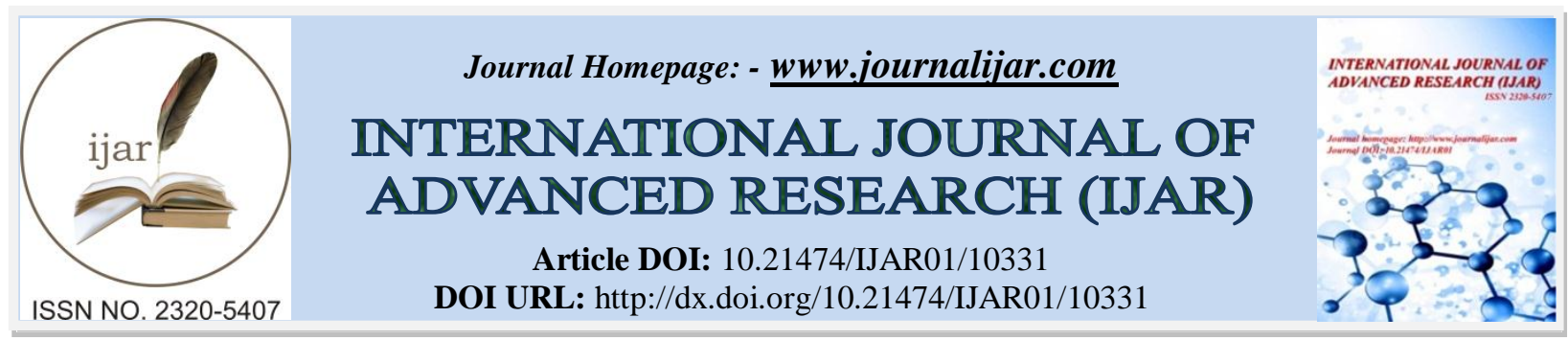

RESEARCH ARTICLE

\title{
A STUDY OF GUIDANCE NEEDS OF SENIOR SECONDARY STUDENTS
}

\author{
Smt. Ranjita Uniyal ${ }^{1}$ and Dr. Geeta Khanduri ${ }^{2}$
}

1. Research Scholar, Department of Education, H.N.B. Garhwal University, Srinagar, Garhwal, Uttarakhand.

2. Professor, Department of Education, H.N.B. Garhwal University, Srinagar, Garhwal, Uttarakhand.

\section{Manuscript Info}

Manuscript History

Received: 25 November 2019

Final Accepted: 27 December 2019

Published: January 2020

Key words:-

Adolescent, Counselling, Guidance Needs

\begin{abstract}
Education is the foundation of human life that makes man the best creature in the world but education without guidance cannot achieve its goal i.e. all round development of students. Guidance is an essential part of education and we can achieve its goal by educating and guiding the students according to their needs of guidance in different areas. This study aimed to identify the guidance needs of senior secondary students. A sample of 200 students (100 males \& 100 females) was selected through simple random sampling technique from different government and private (100 each) senior secondary schools of Dehradun district. Guidance Needs Inventory developed by Dr. J.S. Grewal was used for collection of the data. The findings of the study revealed that students have high need of guidance in all five areas i.e. physical, social, psychological, educational and vocational. Male and female students have no significant difference in their guidance needs. Results also showed that government school students need more guidance in physical area as compared to private school students.
\end{abstract}

Copy Right, IJAR, 2020, All rights reserved.

\section{Introduction:-}

"Show me the heroes that the youth of your country look up to, And I will tell you the future of your country."Idowu Koyenikan

India is a developing country. In the next few decades, India is going to be the country with the largest population of youth in the world. There is immense development potential in India by this youth. This youth can play a huge role to make India as one of the most developed countries in the world but at present youth are indulged in many criminal tendencies such as sexual offenses, drug- addiction, theft etc. The National Crime Record Bureau (NCRB) revealed in its latest data that in 2017, over 40,000 juveniles were caught across the country for involving in various offences, out of which $72 \%$ falling in the age group from 16 to 18 years. These juveniles have committed 1614 rapes and 1456 other sexual assaults (The New Indian Express, 2019). Lack of guidance is one of the main causes behind such problems. Guidance is an integral part of education which induces all round development in children but unfortunately it is badly neglected in our country.

\section{Meaning of Guidance needs:}

Guidance needs are the valuable needs felt by an individual to solve problems and make a wise decision in every aspect of life. Normally, the need for guidance is felt by everyone throughout the life but it is more important during 
secondary education. Senior secondary students have strong counselling needs as perceived by their teachers (Azeez \& Sumangala, 2015). Mostly, the students studying in senior secondary classes are at the stage of adolescence which is the most crucial period of human development phase often marked with problems comparable to storm and strife, as a result of transition from childhood to adulthood (Hall, 1904). Moreover many physiological and psychological changes witness the time, which happens due to sexual maturity and other environmental factors, leading to a big change in the personality.

Adolescence is also an age of dilemma where in a child sometimes moves out of step and behaves like an adult, while he is still treated like a child by his parents and society members. On some occasions adolescents are also conscious about their study, academic achievement, choice of subjects or courses and career options in the future. The conditions through which adolescents move, create stress, anxiety, unstableness and other adjustment problems in them at this particular stage. Therefore understanding of adolescents and their problems, in order to guide them on the right track and make adequate adjustment between the child and society, becomes mandatory for every stakeholder.

Traditionally, parents, elders and more knowledgeable others and experienced members of the societies have provided guidance and advice to their young ones whenever needed but today's situation has become very critical. There is an absolute need of guidance and counselling in schools of India by the professional guidance workers and counselors due to change in family structures and management, working mothers, divorces, single parent families and issues like advancement in technologies, suicide cases and drug abuses among children. Parents also need counselling related to various issues such as acceptance of strengths and weaknesses, interests and aptitude, suitability and career choice of their child, learning disabilities and psychological problems of the child, if any. (Kodad and Kazi, 2014) Professional guidance and counselling programs boost self-esteem and self-confidence of the students and reduce their level of anxiety and depression. These programs impact the development of social and relational skills moderately. (Escapa \& Julia, 2018)

Guidance is a service or process which motivates an individual to do work or solve problems in a better way according to personal abilities, potentialities and capacities. It is a well organized service which helps an individual to take a smart decision according to circumstances and opportunities available. It also helps an individual to recognize aims and objectives and to take actions which are required to achieve them. This assists students to make a wise choice about their courses or vocations by understanding their own interests, aptitude, weaknesses and limitations which in turn helps students to make adequate adjustment by solving their physical, psychological, educational, social and vocational problems by themselves.

Guidance process is based on the philosophy that every individual is different from one another in respect of interest, ability, potential, intelligence and needs. So every individual needs help in different situations of life. This service renders best possible help to facilitate better performance to the person in need. Secondary Education commission has given a comprehensive definition of guidance proclaiming "Guidance involves the difficult art of helping boys and girls to plan their own future wisely in the full light of all the factors that can be mastered about themselves and about the world in which they are to live and work."

According to Knapp, "Guidance is learning about the individual student, helping to understand himself, effect changes in him and his environment which will help him to grow and develop as much as possible."

Mathewson has defined guidance as, "A systematic professional process of helping the individual through education and interpretative procedures to gain a better understanding of his own characteristics and potentialities and to relate himself more satisfactorily to social requirements in accordance with social and moral values."

\section{Types of Guidance:}

1. Physical Guidance: - Adolescents have greater tendency to remain conscious about their physical appearance with a keen desire to look beautiful, handsome and smart but contrary some may develop inferiority complex about their physique, looks, color and complexion which may further lead to low self-esteem, poor selfconfidence, low academic achievement, introvert nature, irritability, anxiety and other adjustment problems. Physical guidance helps adolescents to remain confident about their physical appearance, abilities, potentialities and their uniqueness. This type of guidance includes suggestions which help individuals to maintain their daily 
routine activities to keep them healthy and fit. These activities include diet schedule, exercise routine \& sports activities, regulating sleeping \& study hours of individuals etc.

2. Social Guidance: - Social guidance is a service which helps an individual to improve behaviour within a family, a classroom or a society where an adolescent lives, works or participates in. This is helpful in making adequate adjustment with people around and developing necessary qualities in an individual to become a responsible member of the society and the nation.

3. Psychological Guidance: - Psychological guidance assists an individual to get mental satisfaction by solving mental or psychological problems. In this type of guidance counselor needs a deeper level of understanding of the individuals to find out the root cause of the problems so that the counselor can help them to solve their problems by themselves. This is beneficial for resolving conflicts and developing self-confidence in individuals and helps to take a wise decision independently.

4. Educational Guidance: - Educational guidance is directly related to the problems of students. It is the most important guidance which is required for progress and adjustment of the students in schools and educational institutions. It helps students in developing interest in studies, removing subject matter difficulties, developing the habit of hard work to secure good marks in examination, developing potentialities, abilities \& capacities to the optimum level, getting information about educational opportunities beyond school stage, testing their interest and aptitude and choosing subjects or courses etc. This also helps to know about proper utilization of school holidays.

5. Vocational Guidance: - Vocational guidance is the help given to the students to know about different career options after completion of secondary and senior secondary school stage. It helps them to opt for courses which are suitable to yield job opportunities for them. It imparts information about professional courses, part-time \& self-employable jobs and strategies for fighting in competitive exams to get jobs. It also helps students to choose careers or vocations according to their interests and aptitudes and to prepare for them.

Statement of the problems:

A study of guidance needs of senior secondary students.

\section{Objectives:-}

To study the guidance needs of senior secondary students on the basis of gender and school managements.

\section{Hypotheses:}

1. There will be no significant difference between guidance needs of male $\&$ female senior secondary students.

2. There will be no significant difference between guidance needs of government and private senior secondary school students.

\section{Delimitations of the study:}

1. The students studying in class $11^{\text {th }}$ were selected for the present study.

2. The sample was taken from government and private schools of Vikasnagar Block of Dehradun District (Uttarakhand) only.

\section{Research Method:-}

Research Design:

The descriptive survey method was used for the present study.

\section{Population:}

The population of the study was all senior secondary students studying in government and private schools of Dehradun district of Uttarakhand.

\section{Sample:}

A sample of 200 students was selected by simple random sampling technique. There were 100 students (50 male \& 50 female) from government schools and 100 students (50 male \& 50 female) from private schools selected from Dehradun district.

\section{Tool Used:}

Guidance Needs Inventory prepared and standardized by Dr. J.S. Grewal was used for the data collection. 


\section{Statistical Technique:}

In the present study Arithmetic Mean, S.D and t-test have been used to analyze the data.

\section{Result \& Discussion:-}

Table. 1:- Mean, S.D and $t$ value of guidance needs scores in various areas of male and female senior secondary students.

\begin{tabular}{|c|c|c|c|c|c|c|c|c|}
\hline \multirow[t]{2}{*}{$\begin{array}{l}\text { S. } \\
\text { No. }\end{array}$} & \multirow[t]{2}{*}{ Areas of Guidance needs } & \multicolumn{2}{|c|}{$\begin{array}{l}\text { Male } \\
(\mathrm{N}=100)\end{array}$} & \multicolumn{2}{|c|}{$\begin{array}{l}\text { Female } \\
(\mathrm{N}=100)\end{array}$} & \multirow[t]{2}{*}{$\mathbf{S E}_{\mathrm{m}}$} & \multirow[t]{2}{*}{$\mathrm{t}$ - value } & \multirow[t]{2}{*}{ Level of significance } \\
\hline & & Mean & S.D & Mean & S.D & & & \\
\hline 1. & Physical Area (GNI1) & 11.53 & 6.15 & 11.27 & 5.32 & 0.81 & 0.32 & 0.05 \\
\hline 2. & Social Area (GNI2) & 18.1 & 8.72 & 20 & 9.32 & 1.28 & 1.48 & 0.05 \\
\hline 3. & Psychological Area (GNI3) & 15.2 & 8.57 & 14.9 & 8.55 & 1.21 & 0.25 & 0.05 \\
\hline 4. & Educational Area (GNI4) & 18.3 & 11.4 & 17.4 & 9.91 & 1.51 & 0.60 & 0.05 \\
\hline 5 & Vocational Area (GNI5) & 7.34 & 5.01 & 6.95 & 5.46 & 0.74 & 0.53 & 0.05 \\
\hline \multicolumn{2}{|c|}{ Overall Guidance Needs } & 70.43 & 34.56 & 70.56 & 32.07 & 4.71 & 0.03 & 0.05 \\
\hline
\end{tabular}

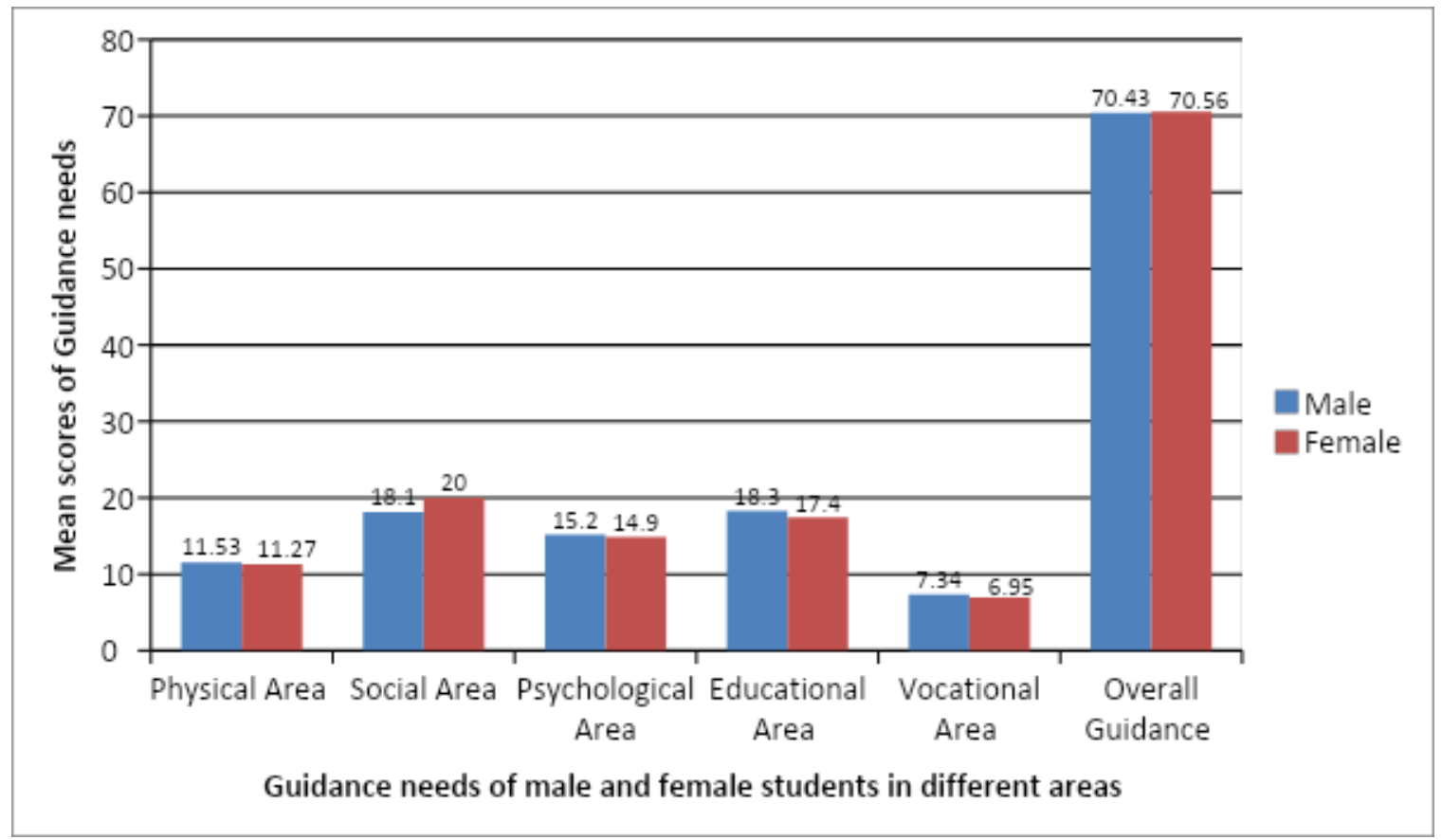

Figure 1:- Guidance needs of male and female senior secondary students.

Table No-1 shows that $\mathrm{t}$-value and mean scores of guidance needs of male and female senior secondary students in Physical area $(\mathrm{t}=0.32)$, Social area (1.48), Psychological area $(\mathrm{t}=0.25)$, Educational area $(\mathrm{t}=0.60)$, Vocational area $(\mathrm{t}=0.53)$ and Overall Guidance Needs $(\mathrm{t}=0.03)$ where in calculated $\mathrm{t}$-value is less than the table value 1.96 at 0.05 level of significance. Therefore, null hypothesis, i.e. there will be no significant difference between guidance needs of male and female senior secondary students in all five areas and overall guidance needs is accepted at 0.05 level of significance. That means male and female students did not vary in all the dimensions of guidance needs. The results are similar to Rao, (2017) as he also found that male and female students have similar guidance needs in all five areas while Nivedita and Singh, (2017) found that female students need more guidance than male students. The Results also revealed that mean scores of guidance needs of male and female senior secondary students fell in high need of guidance in all five areas as well as in overall guidance. Azeez and Sumangala, (2015) also found that senior secondary students have high counselling needs as perceived by their teachers.

Table 2:- Mean S.D and t value of guidance needs scores in various areas of government and private senior secondary school students.

\begin{tabular}{|l|l|l|l|l|l|l}
\hline S/No & Areas of Guidance needs & Government & Private & SE $_{m}$ & t- value & Level of significance
\end{tabular}




\begin{tabular}{|l|l|l|l|l|l|l|l|l|}
\hline & & $(\mathrm{N}=100)$ & \multicolumn{2}{l}{$(\mathrm{N}=100)$} & & \\
\cline { 3 - 7 } & & Mean & S.D & Mean & S.D & & & \\
\hline 1. & Physical Area (GNI1) & 10.54 & 5.62 & 12.26 & 5.75 & 0.80 & 2.15 & 0.05 \\
\hline 2. & Social Area (GNI2) & 18.8 & 9.85 & 19.4 & 8.22 & 1.28 & 0.47 & 0.05 \\
\hline 3. & Psychological Area (GNI3) & 15.4 & 8.4 & 14.7 & 8.7 & 1.21 & 0.58 & 0.05 \\
\hline 4. & Educational Area (GNI4) & 17 & 10.4 & 18.7 & 10.9 & 1.51 & 1.13 & 0.05 \\
\hline 5 & Vocational Area (GNI5) & 6.72 & 4.92 & 7.57 & 5.52 & 0.74 & 1.15 & 0.05 \\
\hline \multicolumn{2}{l}{ Overall Guidance Needs } & 68.39 & 33.48 & 72.6 & 33.05 & 4.71 & 0.89 & 0.05 \\
\hline
\end{tabular}

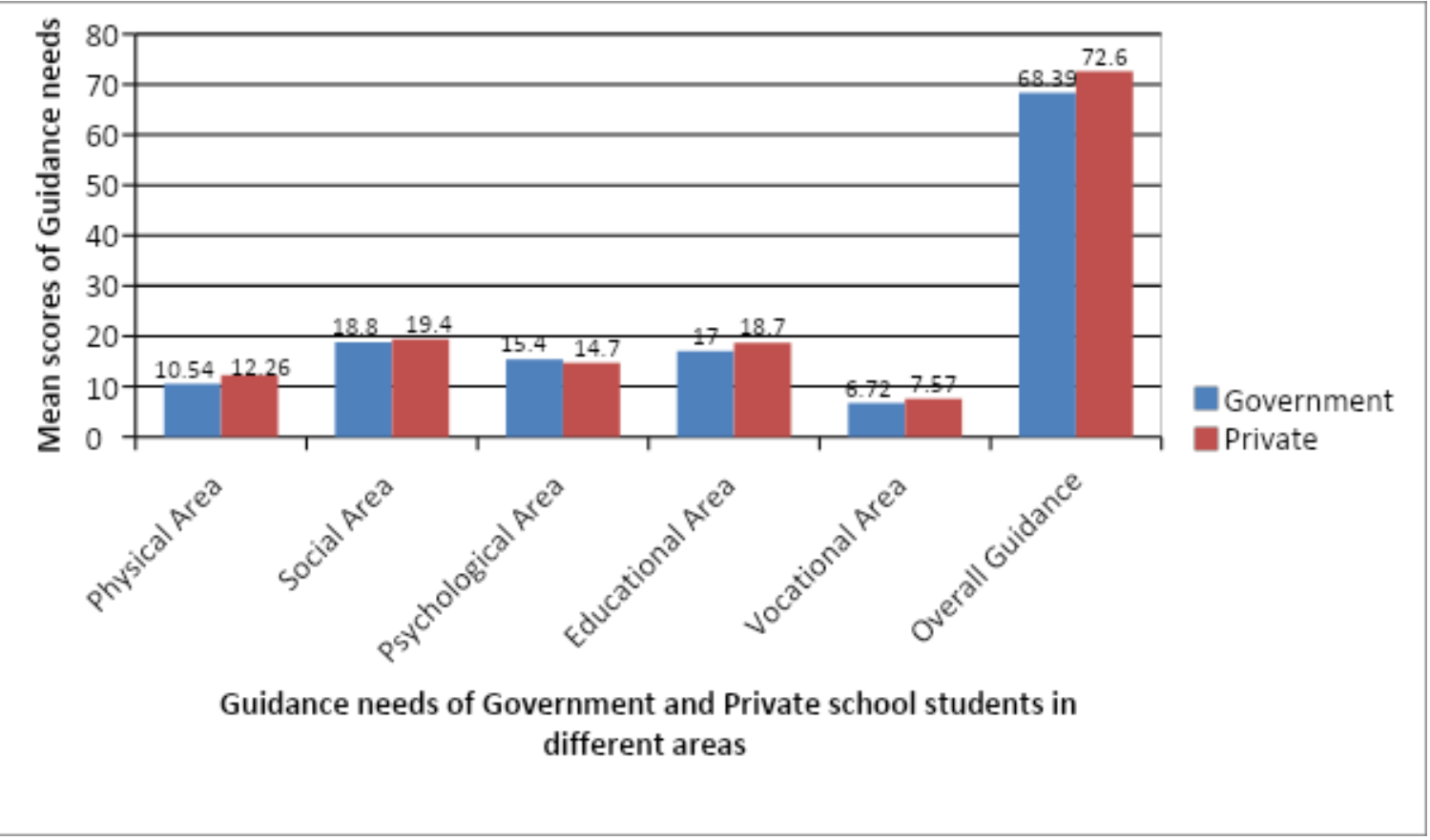

Figure 2:- Guidance needs of Government and Private senior secondary school students.

Table No 2 shows that t-value and mean scores of guidance needs of government and private senior secondary school students in Social area $(\mathrm{t}=0.47)$, Psychological area $(\mathrm{t}=0.58)$, Educational area $(\mathrm{t}=1.13)$, Vocational area $(\mathrm{t}=1.15)$ and Overall Guidance Needs $(\mathrm{t}=0.89)$ where in calculated $\mathrm{t}$-value is less than the table value 1.96 at 0.05 level of significance. Hence null hypothesis that there is no significant difference between guidance needs of government and private senior secondary school students in four dimensions i.e. Social area, Psychological area, Educational area, and Vocational area as well as in Overall Guidance Needs is accepted. The Results also showed that the t-value of guidance needs of government and private senior secondary school students in Physical area $(t=2.15)$ is greater than the table value 1.96 at 0.05 level. This clearly indicates that there is a significant difference between guidance needs of government and private senior secondary school students in Physical area. It means government school students need more guidance in Physical area as compared to private school students while Rao, (2017) found that the guidance needs of government and private school students do not differ significantly in Physical, Educational and Vocational areas but differ significantly in Social and Psychological areas.

\section{Major Findings:}

1. There is no significant difference between guidance needs of male and female senior secondary students in all dimensions of guidance needs.

2. Male and female senior secondary students equally need more guidance in all areas of guidance needs.

3. There is no significant difference between guidance needs of government and private senior secondary school students accept guidance needs in physical area.

4. Government senior secondary school students need more guidance in physical area as compared to private senior secondary school students. 


\section{Conclusion:-}

Development of a nation depends on its youth so proper development of children is the responsibility of the nation. If we know the needs of the child in different areas of life, we can help him to fulfil his needs and can give him wheels to run on the platform of the development. The present study is helpful to achieve this objective. The present study revealed that male and female senior secondary students have high need of guidance in all five areas. These five areas cover almost all dimensions of our growth and development. They need high guidance means they have problems which hinder their development in these areas of life. The reason behind these problems is the complexity of the world around which is increasing day by day. To survive in this complex world a professional guidance along with good education is necessary for all. Therefore each teacher should either be trained in guidance and counselling or at least one guide or counselor should be appointed in each school. This guide or counselor can guide them individually or in a group and if someone has any special kind of problem, then counselor can give him counselling individually to resolve conflicts and solve problems faced by the individual. This will help in smooth and continuous development of the students and indirectly adds to the development of the nation.

\section{References:-}

1. Azeez A. V. P. \& Sumangala V. Counselling needs of higher secondary school students of Kerala: An exploration into the teacher perception. IOSR Journal of Research \& Method in Education (IOSR-JRME). 2015 (May-June); 5(3): 25-28.

2. Bhatnagar R. P. \& Rani Seema.Guidance and Counselling in Education \& Psychology. R.Lall Book Depot, Booksellers \& Publishers, Meerut-250001 (U.P.) India. 2009.

3. Escapa Sandra \& Julia Albert. What impact do guidance and counseling programs have on students? Ivalua, Institut catala d' Avaluacio de Politiques Publiques. 2018 Oct: 1-24. Retrieved from www.ivalua.cat> documents

4. Kochhar S K. Educational and Vocational Guidance in secondary schools. Sterling Publishers Private Limited.2008:7. Retrieved from https://books.google.co.in>about

5. Kodad H. S. \& Kazi S. A. Emerging area of counseling in schools in India. International Journal of Social Sciences. 2014 March; 3(3):44-47.

6. Kumari Sarita \& Tomar Monika. Guidance \& Counselling. Shree Publishers \& Distributers. 20, Ansari Road, Darya Ganj, New Delhi-110002, 2005.

7. Nivedita \& Singh Jay. Comparative study of the Guidance Needs of secondary school students. International Journal of Physical and Social Science. 2017 June; 7(6): 78-87.

8. Rao B. Venkata. Guidance needs of high school students: An analytical study. International Journal of Creative Research Thoughts (IJCRT). 2017 December; 5(4):2046-2053.

9. The New Indian Express. Published 22 Oct, 2019, 10:16 PM, https://www.newindianexpress.com.

10. Nation Building Quotes-Goodreads. Retrieved from https://www.goodreads,com

11. Hall G.Stanley. Storm \& Stress in Adolescence. Retrieved from https://study.com>academy>g-sta. 